International Review of Research in Open and Distributed Learning

Volume 19, Number 2

April - 2018

\title{
A Collaborative Approach to OER Policy and Guidelines Development in the Commonwealth: The Case of Botswana, Cameroon, and Sri Lanka
}
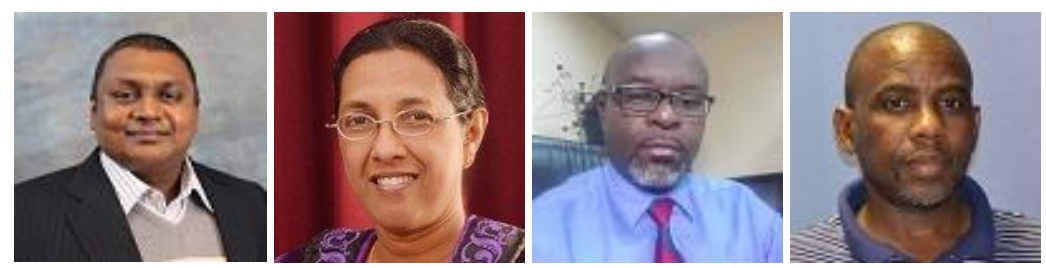

Ishan Sudeera Abeywardena', Shironica P. Karunanayaka ${ }^{2}$, Michael N. Nkwenti ${ }^{3}$, and Lekopanye Tladi ${ }^{4}$ Commonwealth of Learning ${ }^{1}$, The Open University of Sri Lanka ${ }^{2}$, The University of Yaounde I3, Botswana College of Distance and Open Learning ${ }^{4}$

\begin{abstract}
Access to relevant learning resources is an important aspect in ensuring inclusive and equitable quality education and lifelong learning opportunities for all as outlined in the sustainable development goal 4 (SDG4). The Commonwealth of Learning (COL) has identified the development of open educational resources (OER) as a potential answer to these challenges. A total of 29 provincial/regional OER policies and guidelines were developed in Sri Lanka, Botswana, and Cameroon closely involving 608 provincial/regional policymakers from the general education system. The innovation of this project lies in the collaborative approach adopted for OER policy/guideline development where a maximum number of policymakers at the provincial/regional level have been included in the policy development process. Key applications of the approach are mass-sensitization of policymakers, identification of champions in each province or region to drive the OER agenda forward, and the development of policies/guidelines tailored to the specific needs of a particular jurisdiction. The paper will also highlight the success factors, challenges, and the follow-up activities of the project.
\end{abstract}

Keywords: open educational resources, OER, OER policy development, Sri Lanka, Botswana, Cameroon 


\section{Introduction}

The Incheon declaration introduces the sustainable development goal 4 (SDG4) - Education 2030 agenda towards inclusive and equitable quality education and lifelong learning for all where

inclusion and equity in and through education is the cornerstone of a transformative education agenda, and we therefore commit to addressing all forms of exclusion and marginalization, disparities and inequalities in access, participation and learning outcomes. No education target should be considered met unless met by all. We therefore commit to making the necessary changes in education policies and focusing our efforts on the most disadvantaged, especially those with disabilities, to ensure that no one is left behind. (UNESCO, 2015, p.7)

Education stakeholders in developing countries of the Commonwealth are increasingly challenged with the quality of learning outcomes for each learner. According to the UNESCO Institute for Statistics (2010), the quality of learning outcomes for each learner depends on many factors among which are the possession of required textbooks and other didactic materials. Textbooks are considered relevant in improving learning outcomes especially in large class sizes, where often, there is insufficient instructional time. The Global Education Monitoring Report (UNESCO, 2016) observed that, expenditure of a country on learning material is a good indicator of its commitment to providing a quality education for all. Further, it recognizes that the provision of textbooks is critical from both the teachers' and students' perspectives. However, Fredriksen, Brar, and Trucano (2015) highlight that many developing countries do not have the resources to provide sufficient access to learning materials in the general education sector. Considering these challenges, there is a need to identify alternative resources that can supplement the existing textbooks. A review of some literature on textbook provision reveals that OER can offer a cost effective and high-quality solution to this necessity (Cape Town Declaration, 2007; Camilleri, Ehlers, \& Pawlowski, 2014; Adala, 2016).

The 2012 Paris OER Declaration defines open educational resources (OER) as

teaching, learning and research materials in any medium, digital or otherwise, that reside in the public domain or have been released under an open license that permits no-cost access, use, adaptation and redistribution by others with no or limited restrictions. (UNESCO, 2012, p.1)

The Open Educational Resources in the Commonwealth 2016 report (Phalachandra \& Abeywardena, 2016) indicates that the majority of teachers within the Commonwealth perceive OER to be a good solution to improve quality and minimize costs. As stakeholders continue to equip schools with new learning technologies while Internet connectivity continues to improve, especially in developing countries, OER have a real potential to increase access and equity in education.

The Commonwealth of Learning, or COL (www.col.org), is an intergovernmental organization created by Commonwealth Heads of Government to promote the development and sharing of open learning and distance education knowledge, resources, and technologies. Hosted by the Government of Canada and headquartered in Burnaby, British Columbia, Canada, COL is the world's only intergovernmental organization solely concerned with the promotion and development of distance education and open learning. COL actively helps developing nations improve access to quality education and training. In this 
regard, COL's Kuala Lumpur Declaration (Commonwealth of Learning, 2016a) recommends the mainstreaming of OER use by developing strategies and policies at governmental and institutional levels to enhance quality while potentially reducing the cost of education.

In the lead-up to the 2014 Regional Focal Points Meeting, COL's Focal Point for Sri Lanka (Commonwealth of Learning, 2015a), Botswana (Commonwealth of Learning, 2015b), and Cameroon (Commonwealth of Learning, 2015c), had identified top priorities for their countries where COL can further support the national agenda in the next six years. As a follow up, COL, through the Open Educational Resources for Skills Development project, looked to focus on the areas of: (i) improving the content and quality of textbooks; and (ii) upgrading of primary and secondary curriculum in these countries through the use of OER, with the support of the respective Ministry of Education (MoE).

\section{Sri Lanka}

The MoE in Sri Lanka has provincial ministries of education representing the nine provinces which are Central, Eastern, Northern, North-Eastern, North-Western, Sabaragamuwa, Southern, Uva, and Western. While the MoE is responsible for preparing national strategic plans for the general education sector based on national policies, the provincial ministries of education have the autonomy to adopt policies to suit the unique needs of each province in line with national education policies and current reforms (Ministry of Education - Sri Lanka, n.d.).

In Sri Lanka, there are approximately 4 million primary and secondary learners spread across 10,000 plus schools island-wide (Ministry of Education Sri Lanka, 2016). Based on the Education First Sri Lanka report (Ministry of Education Sri Lanka, 2013), the government handles 30 million copies of textbooks a year at a cost of Rs. 3,000 million to provide free textbooks to learners up to General Certificate of Education (G.C.E.) Ordinary Level under the "free education policy." In this regard, OER-based textbooks can be considered as a potential substitute, which could aid in reducing the cost of free textbooks while maintaining a high standard of quality and interactivity.

In 2016, with the guidance of the MoE and in collaboration with the Open University of Sri Lanka (OUSL), COL supported an ambitious project to advocate, sensitize, and develop OER policies for the nine provincial Ministries of Education in Sri Lanka (Karunanayaka, 2016; Karunanayaka \& Abeywardena, 2016). The aim of the project was to provide direction in the use of OER for increasing access to quality learning materials and to support quality teaching and learning in the general education system.

Using Sri Lanka as the model, similar projects were initiated in Botswana and Cameroon to develop provincial OER policies. However, further to advice from the MoE in Botswana and Cameroon, the word "policy" was replaced with "guideline" to allow the execution of the project with minimum bureaucratic interference. Also, Botswana and Cameroon have "regions" as opposed to "provinces." Therefore, the project set out to develop "regional OER guidelines" within these two countries.

\section{Botswana}

Botswana is faced with a continued decline in student performance, which has been attributed to poor quality education. According to Mphale and Mhlauli (2014), students' academic performance has been declining at an alarming rate since 2010; one of the factors contributing to decline in academic 
performance is the quality of teaching and learning resources available. According to UNESCO, Botswana is the only country in Sub-Saharan Africa to have adequate provision of textbooks close to a 1:1 ratio for all subjects and all secondary grades (UNESCO, 2016). However, the average cost for a set of textbooks from grades 9 to 11 is USD 99.60 and the government needs a budget equivalent to $1.8 \%$ of the Gross National Product (GNP) to maintain this level of access (Fredriksen, Brar, \& Trucano, 2015). Given this scenario, adopting OER would enable students and teachers to access a larger pool of quality resources for use as supplementary content to prescribed textbooks. This will translate into immediate positive utilization of the ICT infrastructure currently being provided to the schools through both government and private sector participation projects.

In Botswana, the Ministry of Education and Skills Development (MoESD) is the headquarters of education where national administrative responsibilities and policy formulation is undertaken. There are 10 regional operations offices around the country undertaking administrative responsibilities of the MoESD. The 10 MoESD regional operations offices are in the Kgatleng Region, Kweneng Region, Southern Region, Kgalagadi Region, Gantsi Region, North West Region, Chobe Region, North East Region, Central Region, and South East Region. While the MoESD is responsible for developing national policies, the regions are responsible for ensuring that these policies are implemented within their administrative jurisdictions (Tladi, 2016).

An advocacy program was conducted by COL in Botswana with the objective of providing direction for the use of OER to increase access to quality teaching and learning material in the general education system. The project developed OER guidelines for the 10 regional offices in Botswana with the consent and support from the MoESD.

\section{Cameroon}

On account of its bi-cultural French/English heritage, Cameroon's educational system is diverse and multi-faceted. Efforts to supply schools in Cameroon with textbooks and course books are constantly challenged with the recurrent economic downturn due to the falling prices of raw materials in the world market. A 2015 World Bank report shows that the average course book-to-learner ratio in Cameroon is 1:12 (Fredriksen et al., 2015). Disparities are greater in the three northern regions of Cameroon where accessibility to some areas over the last three years has been jeopardized by terrorist attacks. Only $11 \%$ of learners in these areas have access to at least one textbook, while $17 \%$ of classrooms operate without a single textbook in French or English. The 2013/2014 statistical yearbook of the Ministry of Basic Education (2014) reported that in most classrooms, each French/English reading book is shared amongst 19 learners and each mathematics book is shared amongst 17 learners. The 2015 World Bank Report (Fredriksen et al., 2015) also noted that the price of course books is very high and undoubtedly hinders a vast majority of parents from purchasing textbooks for their children.

To potentially address these issues, COL worked with the Ministries of Basic Education (MINEDUB) and Secondary Education (MINESEC) of Cameroon to launch a national advocacy and sensitization project that introduced OER to policymakers in the 10 regions of the country: Adamawa, Centre, East, Far North, Littoral, North, North West, West, South, and South West. Regional OER guidelines were developed by each regional delegation for mainstreaming OER into the general education system locally (Nkwenti, 2017). 
This paper details the collaborative approach adopted for OER policy/guideline development where a maximum number of policymakers at the provincial/regional level have been included in the policy development process. The paper also highlights the success factors, challenges, and the follow up activities of the project.

\section{Methodology}

The policy/guideline development in each country was done in four stages. The first stage was to prepare a country specific OER policy/guideline template. A consultant was hired from each country who had a unique knowledge of the education system in general, the specific requirements of each province or region as well as an in depth understanding of how OER can be implemented in these jurisdictions. The consultant then drafted the policy/guideline document taking into consideration the literature; existing policy documents such as the COL's Institutional OER Policy Template (Commonwealth of Learning, 2016b), the Government Policy Development Template (Butcher, 2012), and national education policies and reforms. The drafting of the document followed an iterative process which benefitted from peer review and expert feedback before finalizing. The first version was compiled in English. However, the document was translated into French in Cameroon to accommodate the Francophone regions.

The second stage concentrated on conducting advocacy meetings with the provincial/regional policymakers. The first step in this process was to brief the MoE regarding the project with the aim of gaining their full cooperation. COL officially informed the secretaries to the MoE in each country regarding the consultant, the nature of the project, and the expected outputs of the project which are to:

- Prepare a draft OER policy/guideline template that caters to the requirements of the provinces/regions;

- Sensitize and seek collaboration for the project from the key stakeholders at the MoE;

- Build awareness among key stakeholders in the provinces/regions on the concept and potential impact of OER;

- Advocate the necessity and benefits of a provincial/regional OER policy/guideline for education;

- Initiate the process of drafting OER policies/guidelines for each province/region;

- Identify champions in each province/region who will draft the OER policies/guidelines;

- Provide on-going online support/follow-up to champions leading up to a final draft policy/guideline;

- Produce a project report to be presented to the MoE that will facilitate the adoption and implementation of the policies.

Following the correspondence from COL, the consultant met with the officials of the MoE to formulate a plan of action for the project. The MoE would then issue an official letter to all provinces/regions 
instructing them to extend their full cooperation to the success of the project. Based on the advice of the MoE, the consultant scheduled field visits to each of the provinces/regions as shown in Appendix A.

To facilitate the field visits and the sensitization process, COL had provided the consultants with highquality material on OER creation, use, and policy development in the forms of printed books, toolkits, PowerPoint slides, and videos. The consultant used these materials along with the OER policy template created to conduct the advocacy and sensitization of the key policymakers at each province/region. All staff of the provincial/regional offices were invited to participate in the meetings.

One champion had been identified from each province/region during the field visits to be the contact person for stage three. During this stage the consultant coordinated with the champion to follow-up on the progress with respect to the development of the provincial/regional OER policy/guideline draft. Virtual support was provided via email, skype, and phone to the champions who were tasked with gathering the feedback from the policymakers in the province/region and finalizing the draft document.

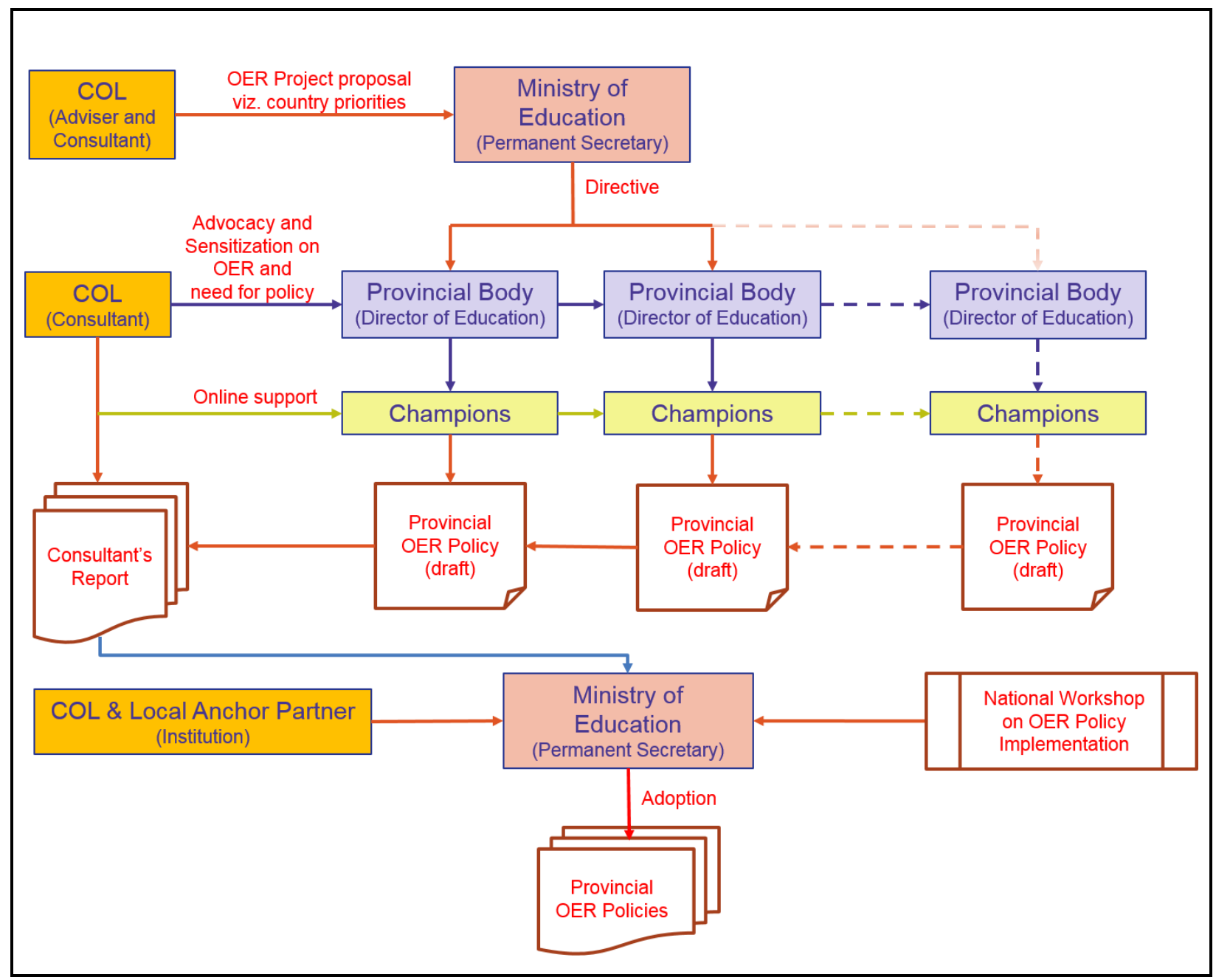

Figure 1. Collaborative approach to provincial/regional OER policy/guidelines development. Adapted from "A bottom-up approach to OER policy development," by I.S. Abeywardena, 2017, Proceedings of the Creative Commons Global Summit 2017, Toronto. Licensed under CC-BY 4.o International license. 
The final stage was to collect all the draft provincial/regional OER policy/guideline documents and prepare a project report which outlined the process, efforts, and lessons learned. This report was shared with the MoE for further action regarding adopting and implementing the policies/guidelines developed. Figure 1 illustrates the model used for developing OER policies using the collaborative approach.

\section{Results}

The key outputs of the project are (i) provincial/regional OER policy/guideline templates; (ii) advocacy and sensitization of key policymakers in the education sector in three countries; (iii) development of draft provincial/regional OER policies/guidelines tailored to the local context; and (iv) project reports which were shared with the MoE highlighting the way forward with respect to adopting and implementing the policies. Table 1 summarizes the key outputs of the project.

Table 1

Key Outputs of the Project

\begin{tabular}{|c|c|c|c|c|c|}
\hline $\begin{array}{l}\text { Country and } \\
\text { project } \\
\text { duration }\end{array}$ & $\begin{array}{l}\text { Number of } \\
\text { provinces } \\
\text { or regions }\end{array}$ & $\begin{array}{l}\text { OER policy or } \\
\text { guideline } \\
\text { template }\end{array}$ & $\begin{array}{l}\text { Number of } \\
\text { policymakers } \\
\text { sensitized }\end{array}$ & $\begin{array}{l}\text { Number of } \\
\text { policies or } \\
\text { guidelines } \\
\text { developed }\end{array}$ & $\begin{array}{l}\text { Final project } \\
\text { report }\end{array}$ \\
\hline $\begin{array}{l}\text { Sri Lanka } \\
\text { (5 months) }\end{array}$ & 9 & $\begin{array}{l}\underline{\text { http://oasis.col.o }} \\
\underline{\mathrm{rg} / \mathrm{handle} / 11599 /} \\
\underline{2360}\end{array}$ & 58 & 9 & $\begin{array}{l}\underline{\text { http://oasis.co }} \\
\underline{\text { l.org/handle/1 }} \\
\underline{1599 / 2386}\end{array}$ \\
\hline $\begin{array}{l}\text { Botswana } \\
\text { ( } 4 \text { months) }\end{array}$ & 10 & $\begin{array}{l}\underline{\text { http://oasis.col.o }} \\
\underline{\mathrm{rg} / \mathrm{handle} / 11599 /} \\
\underline{2438}\end{array}$ & 157 & 10 & $\begin{array}{l}\underline{\text { http://oasis.co }} \\
\underline{\text { l.org/handle/1 }} \\
\underline{1599 / 2437}\end{array}$ \\
\hline $\begin{array}{l}\text { Cameroon } \\
\text { (3 months) }\end{array}$ & 10 & $\begin{array}{l}\underline{\text { http://oasis.col.o }} \\
\underline{\mathrm{rg} / \mathrm{handle} / 11599 /} \\
\underline{2673 \text { (EN) }} \\
\underline{\text { http://oasis.col.o }} \\
\underline{\mathrm{rg} / \mathrm{handle} / 11599 /} \\
\underline{2674} \text { (FR) }\end{array}$ & 393 & 10 & $\begin{array}{l}\underline{\text { http://oasis.co }} \\
\underline{\text { l.org/handle/1 }} \\
\underline{1599 / 2672}\end{array}$ \\
\hline \multicolumn{3}{|l|}{ Total } & 608 & 29 & \\
\hline
\end{tabular}

The key takeaways from the project based on the feedback provided by the participants are summarized in Table 2. 
Table 2

Key Takeaways From the Project Based on Participant Feedback

\begin{tabular}{|c|c|}
\hline Aspect & Feedback \\
\hline $\begin{array}{l}\text { Concept of OER and its } \\
\text { significance }\end{array}$ & $\begin{array}{l}\text { - OER, Creative Commons, Open Licensing, and the } 5 \text { Rs are new } \\
\text { concepts for many policymakers in the education sector. } \\
\text { Having access to free and open resources as OER is very beneficial } \\
\text { to the school education system. } \\
\text { - OER will be used as supplementary resources to the material } \\
\text { provided by Government. } \\
\text { - Creation and use of supplementary resources are taking place in } \\
\text { certain jurisdiction without the proper underpinning technological } \\
\text { and theoretical knowledge. } \\
\text { - It is important to raise awareness about these concepts, and } \\
\text { motivate teachers to engage in OER creation and sharing. } \\
\text { Access to OER can help mitigate poor student performance and } \\
\text { contribute towards improving the quality of student results. } \\
\text { OER provide teachers with an opportunity to reduce dependence on } \\
\text { the prescribed textbooks. } \\
\text { There is a need to embrace the spirit of sharing to change the world } \\
\text { because people will change when they have the knowledge. }\end{array}$ \\
\hline Need for an OER policy & $\begin{array}{l}\text { - The need for an OER policy is accepted and its significance is } \\
\text { realized. } \\
\text { - OER can be used to cut down the cost of education financing. } \\
\text { Proper guidelines from the central Ministry of Education is needed } \\
\text { for adoption and implementation. } \\
\text { There is a need to involve other stakeholders such as writers, } \\
\text { writers' associations, and publishers in OER initiatives. } \\
\text { OER sensitization must filter down to the teacher training } \\
\text { institutions to ensure that this valuable knowledge and skills are } \\
\text { part of the teacher training curriculum. }\end{array}$ \\
\hline Challenges & $\begin{array}{l}\text { - Technical infrastructure and facilities in schools need to be } \\
\text { upgraded. } \\
\text { - A more conducive "school climate" and teaching-learning } \\
\text { environment is required. } \\
\text { - Increasing teacher motivation to engage in innovative teaching- } \\
\text { learning processes and material development is crucial. } \\
\text { - Schools and teachers need to be encouraged to promote the spirit } \\
\text { and habit of sharing locally produced content for the benefit of } \\
\text { students. } \\
\text { - Time constraint is a severe challenge faced by all, including teachers } \\
\text { and policymakers. }\end{array}$ \\
\hline
\end{tabular}




\begin{tabular}{|c|c|}
\hline Suggestions & $\begin{array}{l}\text { - } \quad \text { Existing ICT initiatives, facilities, and resources to be used to } \\
\text { promote OER creation, sharing, and use by teachers. } \\
\text { The central Ministry of Education needs to coordinate and regulate } \\
\text { - } \quad \text { schools with good connectivity should assist others with access to } \\
\text { OER content by downloading and sharing. } \\
\text { - Schools should consider allowing students to bring mobile devices, } \\
\text { such as smartphones and tablets, to school which they could use to } \\
\text { access and take advantage to freely available online resources such } \\
\text { as OER. } \\
\text { - Raising awareness and skill development of teachers is required. } \\
\text { - } \text { OER can also be used for self-development of staff through } \\
\text { continuous knowledge acquisition and lifelong learning. } \\
\text { Encouraging teachers to create OER in their native languages is } \\
\text { very important. } \\
\text { - Providing guidance, support, and motivation for teachers is needed. } \\
\text { Collections of already developed materials should be properly } \\
\text { catalogued to increase access. } \\
\text { Creating "interest groups" of school teachers and others at } \\
\text { provincial/regional level would be useful. } \\
\text { OER integration can be linked with existing initiatives at } \\
\text { school/provincial/regional levels (e.g., LMS, e-Studios, Open } \\
\text { Schools) } \\
\text { A proper monitoring and evaluation system needs to be put in } \\
\text { place. }\end{array}$ \\
\hline
\end{tabular}

\section{Discussion}

Based on COL's publication A Government Policy Development Template to Progress Effective Implementation of Open Educational Resources (Butcher, 2012), a few key stages are to be followed when developing a national OER policy. One of the key stages is a consultation process with key stakeholders. When considering the national consultation process, usually only a few top level stakeholders participate in these meetings (Commonwealth of Learning, 2017a; Commonwealth of Learning, 2017b). Therefore, this process largely isolates the actual implementers of the policy in these provinces and regions during the development stage. Furthermore, the implementers of the policy would not be as sensitized about OER as the top-level stakeholders participating in the consultation process. In turn, this results in a lack of ownership by the policy implementers.

\section{The Collaborative Approach to OER Policy Development}

The innovation of this project lies in the collaborative approach adopted for OER policy/guideline development where a maximum number of policymakers at provincial/regional levels have been included in the policy development process. A key application of this approach is the mass-sensitization of policymakers where 608 key officials have been sensitized in the three countries (Table 1) on the concept of OER and the impact it would have in the general education system. The identification of champions in each province or region also helped to establish a key contact person who would drive the OER agenda 
forward in the province/region. In the long run, this will be immensely beneficial to the MoE with respect to implementing the OER policies and mainstreaming OER. Further, self-motivated individuals would proceed to pilot OER within their capacities due to the new found knowledge and skills.

Another key application of developing OER collaboratively is that the policy/guideline documents can be tailored to the specific needs of a particular province or region as summarized in Table 2. These might be different and more sensitive than the needs addressed in an overarching national OER policy. For example, in Sri Lanka, there are two main mediums of instruction, which are Sinhala and Tamil. The Sinhala schools are predominantly based in the Southern region while the Northern region comprise of Tamil speaking schools. Furthermore, there are cultural differences which are linked to the two languages in addition to the historical nuances which have been imposed due to a three decade long civil war. By allowing provinces to have an independent OER policy, they are able to address the unique needs of the schools, teachers, and students. Another example is Cameroon where there are Anglophone and Francophone regions. The development of regional OER guidelines allowed the policymakers to customize the policies to suit the cultural and language context in their jurisdiction. Feedback from the far north region reads:

After diligently reading through the document, your proposals are pertinent. We think that the document will contribute in resolving the problem of lack of school textbooks in our educational system if it is adopted. While encouraging you, receive our sincere congratulations for the initiative. From the Regional Delegation of Secondary Education, Far North. (Nkwenti, 2017)

\section{Success Factors}

The project can be considered quite large-scale given that it covered three countries and 29 provinces/regions. The geographical isolation of some of these provinces/regions, political volatilities, natural disasters, cultural nuances, and language barriers, among others, challenged the project from the inception. However, the project successfully developed 29 provincial/regional OER policies/guidelines while advocating and sensitizing a large pool of policymakers on the potential impact of OER. One of the key factors behind the successful completion of the project is the cooperation and patronage received by the MoE. The directives issued by the MoE enabled the consultants to achieve the objectives of the project with a high success rate. Another factor which contributed to the success is the field visits; the physical presence of the consultant at the provinces/regions and the use of printed and digital OER to sensitize the participants, allowed them to relate OER to the needs of their jurisdiction. However, the major success factor of the project was the passion, persistence, and perseverance of the consultants who truly believed in the potential of OER for increasing access and equity in their countries.

\section{Challenges Faced}

In Sri Lanka, one of the major challenges was the busy work schedules of officials in the provincial Ministries of Education and Departments of Education. Although they were very aware of the importance of OER for the future of the general education system in the country, certain other official matters took priority. Another factor which compounded this was the natural disaster situation declared in Sri Lanka due to severe flooding and the blast in a military complex that affected hundreds of schools. Due to these barriers, the project faced some delays and limited participation in Sri Lanka. 
In Botswana, the preparations for its 5oth anniversary celebrations interfered with scheduling of the field visits as the government officials were preoccupied. Lack of communication was another issue encountered due to the poor connectivity of the rural regions. This hindered the online support provided to champions during the finalization stage of the guidelines. The large size of the country made travel to all 10 regions extremely challenging, physically and logistically. Lastly, a restructuring of the ministries in Botswana during the project made the final compilation of the report somewhat challenging. This restructuring exercise resulted in separation of the MoESD into two new ministries: one for Basic Education and another for Tertiary Education, Research, Science, and Technology. The OER initiative was then assigned to the Ministry of Basic Education. This move has therefore created a need for resensitization of the new leadership at this ministry on OER.

In Cameroon, travelling to the different regions was an arduous task due to the nature of roads and unstable flight schedule. The consultant's vehicle regularly suffered breakdowns due to the nature of the roads. Further, two regional delegates did not circulate the information about the scheduled field visit on time, even though they received notice two weeks earlier. This resulted in delays in an already tight schedule. The bilingual nature of the country required that the regional OER policy template and the PowerPoint presentations be translated into French. This proved to be very challenging because the consultant had to contract the services of a translator.

\section{Follow-up Activities}

A National Workshop on Provincial OER Policy Implementation for the nine provinces in Sri Lanka was conducted in February 2017 by COL in partnership with the MoE and the OUSL. The workshop resulted in finalizing the implementation plans for the nine policies and increasing capacity in OER for 42 policymakers in the general education system. Echoing the thoughts by the Minister of Education, the Secretary stated that they consider OER to be a viable method for guaranteeing 13 years of education for all Sri Lankan children and to achieve the Prime Minister's vision of digital textbooks by 2020. Once implemented, the policies will potentially affect 4 million learners in 10,000 schools in Sri Lanka. The workshop also resulted in the National Colleges of Education pledging to make OER a part of the curriculum for training teachers. Based on the success of this follow-up model, similar national workshops on regional OER guideline implementation are due to be organized in Botswana and Cameroon.

\section{Conclusion}

In 2016, the Commonwealth of Learning (COL) undertook an ambitious project to develop OER policies and guidelines for nine provinces in Sri Lanka and 10 regions in Botswana and Cameroon each. The project was conducted by local consultants with the assistance of the MoE within the scope of the general education system. The consultants travelled to each province/region in the country and interacted with key policymakers to advocate the use of OER and sensitize them on how OER can supplement existing textbooks for increased access and equity. Further, the policymakers collaboratively developed draft OER policies/guidelines, taking into consideration the unique cultural, social, political, and language requirements of their province or region. Champions were identified from each region to gather feedback on the process and finalize the draft policies to be submitted to the MoE. 
The innovation of this project is the adoption of a collaborative approach to OER policy development. Traditionally, OER policy development is conducted through a high-level consultation consisting of a limited number of stakeholders. As a result, the officials who are responsible to implement the policies at the provincial/regional level have little ownership of the process and minimal knowledge of the potential impact OER can make in their respective jurisdictions. Through the collaborative approach, we were able to develop 29 provincial/regional OER policies/guidelines in three countries within a duration of approximately six months. Furthermore, we were able to sensitize 608 provincial/regional policymakers on the benefits of using OER as supplements to the school curriculum. Additionally, the development of provincial/regional OER policies/guidelines, independent of an overarching national policy, allowed the local policymakers to contextualize the policies/guidelines according to the cultural, social, political, and language needs. The identification of provincial/regional champions allowed for quick feedback and finalization of the draft policies/guidelines to be presented to the MoE for adoption and implementation. The champions also act as enablers to mainstreaming OER in the long run.

This project makes a significant contribution to the body of knowledge in terms of OER policy development for the general education system within Commonwealth countries. The collaborative approach adopted is a much more inclusive approach to OER policy development and results in increased ownership and mass-sensitization of key stakeholders across countries. Based on the success of the follow-up National Workshop on Provincial OER Policy Implementation held in Sri Lanka, similar implementation workshops are planned for Botswana and Cameroon.

\section{Acknowledgements}

This project was funded as part of the Grant \#2015-2585 generously made by The William and Flora Hewlett Foundation, USA.

Mr. S. Hettiarachchi, Secretary to the Ministry of Education, Sri Lanka; Mr. W. M. Bandusena, former Secretary to the Ministry of Education, Sri Lanka; Mr. S.U. Wijeratne, Additional Secretary, Planning and Performance Review at the Ministry of Education; Secretaries and Asst. Secretaries of provincial Ministries of Education, Sri Lanka; Provincial Directors of Education (PDEs), Additional PDEs, DDEs, ADEs, and the Provincial Departments of Education, Sri Lanka; and the Open University of Sri Lanka (OUSL).

Dr Theophilus Mooko, Permanent Secretary; Mr. Simon Coles and Ms. Helen Chilisa, Deputy Permanent Secretaries to the Ministry of Education and Skills Development, Botswana; Directors and staff of the MoESD Regional Centers of Botswana; and Botswana College of Distance and Open Learning (BOCODOL).

Ministers of Basic and Secondary Education, Cameroon; Professor Leke Tambo Ivo, Secretary General of the Ministry of Secondary Education and COL Focal Point for Cameroon; and Regional Delegates, Regional Inspectors Coordinator, Inspectors Coordinator of Education, Regional Pedagogic Inspectors, and Regional Pedagogic Advisers of Cameroon. 


\section{References}

Abeywardena, I. S. (2017). A bottom-up approach to OER policy development. Proceedings of the Creative Commons Global Summit 2017. Toronto. Retrieved from http://sched.co/AFM5

Adala, A. A. (2016). Current state of advancement of open educational resources in Kenya. UNESCO Institute for Information Technologies in Education. Retrieved from http://iite.unesco.org/pics/publications/en/files/3214744.pdf

Butcher, N. (2012). A government policy development template to progress effective implementation of open educational resources (OER). Burnaby: Commonwealth of Learning. Retrieved from http://hdl.handle.net/11599/2336

Camilleri, A. F., Ehlers, U. D., \& Pawlowski, J. (2014). State of the art review of quality issues related to open educational resources (OER). Luxembourg: Publications Office of the European Union. Retrieved from http://www.pedocs.de/volltexte/2014/9101/pdf/European Commission 2014 OER.pdf

Cape Town Declaration. (2007). Cape Town open education declaration: Unlocking the promise of open educational resources. Retrieved from http://www.capetowndeclaration.org/

Commonwealth of Learning. (2015a). Sri Lanka 2012-2015: Country report. Burnaby: Author. Retrieved from http://hdl.handle.net/11599/988

Commonwealth of Learning. (2015b). Botswana 2012-2015: Country report. Burnaby: Author. Retrieved from http://hdl.handle.net/11599/954

Commonwealth of Learning. (2015c). Cameroon 2012-2015: Country report. Burnaby: Author. Retrieved from http://hdl.handle.net/11599/956

Commonwealth of Learning. (2016a). 2016 Kuala Lumpur declaration. Kuala Lumpur: 8th PanCommonwealth Forum. Retrieved from http://hdl.handle.net/11599/2661

Commonwealth of Learning. (2016b). Institutional OER policy template. Burnaby: Author. Retrieved from http://hdl.handle.net/11599/2361

Commonwealth of Learning. (2017a). Towards National policy guidelines on open educational resources in Malaysia. Burnaby: Author. Retrieved from http://hdl.handle.net/11599/2739

Commonwealth of Learning. (2017b). Towards a national policy on open educational resources in Bangladesh. Burnaby: Author. Retrieved from http://hdl.handle.net/11599/2740

Fredriksen, B., Brar, S., \& Trucano, M. (2015). Getting textbooks to every child in SubSaharan Africa: Strategies for addressing the high cost and low availability problem. Washington, DC: World Bank. Retrieved from 
https://openknowledge.worldbank.org/bitstream/handle/10986/21876/9781464805400.pdf;seq uence

Karunanayaka, S. P. (2016). Provincial OER policy development, Sri Lanka - Consultant report. Burnaby: Commonwealth of Learning. Retrieved from http://hdl.handle.net/11599/2386

Karunanayaka, S. P., \& Abeywardena, I. S. (2016). Advocacy, sesitization and development of OER Policy for provincial education ministries in Sri Lanka. Proceedings of the 8th Pan-Commonwelath Forum. Kuala Lumpur. Retrieved from http://hdl.handle.net/11599/2626

Ministry of Basic Education. (2014). Statistical yearbook for 2013-2014 school year. Cameroon: MINEDUB.

Ministry of Education - Sri Lanka. (n.d.). Retrieved from www.moe.gov.lk

Ministry of Education Sri Lanka. (2013). Education first Sri Lanka - Ministry of education. Colombo: Author. Retrieved from www.moe.gov.lk/sinhala/images/.../Education First SL/Education First SL.pdf

Ministry of Education Sri Lanka. (2016). School census preliminary reports - Ministry of education. Colombo: Author. Retrieved from www.moe.gov.lk/english/images/Statistics/stat201516/2016 new3.pdf

Mphale, L. K., \& Mhlauli, M. B. (2014). An Investigation on students academic performance for junior secondary schools in Botswana. European Journal of Educational Research, 3(3), 111-112. Retrieved from http://files.eric.ed.gov/fulltext/EJ1086046.pdf

Nkwenti, M. N. (2017). Developing regional OER guidelines in Cameroon: Consultant's report. Burnaby: Commonwealth of Learning. Retrieved from http://hdl.handle.net/11599/2672

Phalachandra, B., \& Abeywardena, I. S. (2016). Open educational resources in the Commonwealth 2016. Burnaby: Commonwealth of Learning. Retrieved from http://hdl.handle.net/11599/2441

Tladi, L. (2016). Developing regional OER guidelines in Botswana: Consultant's report. Burnaby: Commonwealth of Learning. Retrieved from http://hdl.handle.net/11599/2437

UNESCO. (2012). 2012 Paris OER declaration. Paris: World OER Congress. Retrieved from http://www.unesco.org/new/fileadmin/MULTIMEDIA/HQ/CI/CI/pdf/Events/Paris\%20OER\%2 oDeclaration 01.pdf

UNESCO. (2015). Education 2030: Incheon declaration and framework for action. Incheon, South Korea: Author. Retrieved from http://unesdoc.unesco.org/images/0024/002432/243278e.pdf

UNESCO. (2016). Global education monitoring report. Paris: Author. Retrieved from http://en.unesco.org/gem-report/every-child-should-have-textbook\#sthash.Af6vGjHD.dpbs 
UNESCO Institute for Statistics. (2010). Global education digest 2010: Comparing education statistics across the world. Montreal, Quebec: Author. 


\section{Appendix A}

\section{Field Visit Schedules}

Table A1

Field Visit Schedule for the Nine Provinces of Sri Lanka

\begin{tabular}{|c|c|c|}
\hline Province & Date and time & Venue \\
\hline Northern & $\begin{array}{l}\text { 20/o4/2016 } \\
\text { 2.00-4.00 p.m. }\end{array}$ & $\begin{array}{l}\text { Provincial Department of } \\
\text { Education-NP, Jaffna. }\end{array}$ \\
\hline North-Central & $\begin{array}{l}22 / 04 / 2016 \\
10.00 \text { am- } 12.00 \text { noon }\end{array}$ & $\begin{array}{l}\text { Chief Ministry-NCP, } \\
\text { Anuradhapura. }\end{array}$ \\
\hline Central & $\begin{array}{l}18 / 05 / 2016 \\
11.00 \mathrm{am}-1.00 \mathrm{pm}\end{array}$ & $\begin{array}{l}\text { Provincial Department of } \\
\text { Education CP, Kandy. }\end{array}$ \\
\hline North-Western (Wayamba) & $\begin{array}{l}18 / \mathrm{o} 5 / 2016 \\
2.30 \mathrm{pm}-4.30 \mathrm{pm}\end{array}$ & $\begin{array}{l}\text { Provincial Department of } \\
\text { Education -NWP, Kurunegala. }\end{array}$ \\
\hline Sabaragamuwa & $\begin{array}{l}24 / 05 / 2016 \\
12.00 \text { noon }-2.00 \mathrm{pm}\end{array}$ & $\begin{array}{l}\text { Provincial Department of } \\
\text { Education -SaP, Ratnapura. }\end{array}$ \\
\hline Southern & $\begin{array}{l}29 / 06 / 2016 \\
2.00-4.00 \mathrm{pm}\end{array}$ & $\begin{array}{l}\text { Provincial Department of } \\
\text { Education -SP, Galle. }\end{array}$ \\
\hline Uva & $\begin{array}{l}04 / 07 / 2016 \\
2.00-4.00 \mathrm{pm}\end{array}$ & $\begin{array}{l}\text { Provincial Department of } \\
\text { Education -UP, Badulla. }\end{array}$ \\
\hline Western & $\begin{array}{l}04 / 08 / 2016 \\
7.30-9.30 \mathrm{am}\end{array}$ & $\begin{array}{l}\text { Provincial Department of } \\
\text { Education -WP, Greenpath, } \\
\text { Colombo } 7 .\end{array}$ \\
\hline Eastern & $\begin{array}{l}08 / 08 / 2016 \\
1.00-3.00 \mathrm{pm}\end{array}$ & $\begin{array}{l}\text { Provincial Department of } \\
\text { Education -EP, Trincomalee. }\end{array}$ \\
\hline
\end{tabular}

Table A2

Field Visit Schedule for the 10 Regions of Botswana

\begin{tabular}{|l|l|l|}
\hline Region & Date and time & Venue \\
\hline Southern & $\begin{array}{l}13 / 09 / 2016 \\
0830-1200 \mathrm{hr}\end{array}$ & Kanye Education Centre \\
\hline Kweneng & $\begin{array}{l}14 / 09 / 2016 \\
0800-1200 \mathrm{hrs}\end{array}$ & Molepolole Regional Office \\
\hline
\end{tabular}




\begin{tabular}{|c|c|c|}
\hline North East & $\begin{array}{l}\text { 15/o9/2016 } \\
0930-1200 h r s\end{array}$ & $\begin{array}{l}\text { Francistown Ntshe House } \\
\text { Regional Offices }\end{array}$ \\
\hline Chobe & $\begin{array}{l}\text { 16/o9/2016 } \\
\text { o80o-130ohrs }\end{array}$ & Kasane Education Centre \\
\hline North West & $\begin{array}{l}\text { 19/o9/2016 } \\
1000-1300 h r s\end{array}$ & Maun Education Centre \\
\hline Gantsi & $\begin{array}{l}20 / 09 / 2016 \\
\text { o80o - 1130hrs }\end{array}$ & Gantsi Education Centre \\
\hline Kgalagadi & $\begin{array}{l}22 / 09 / 2016 \\
\text { o80o - 120ohrs }\end{array}$ & $\begin{array}{l}\text { Kang NonFormal / BOCODOL } \\
\text { Centre }\end{array}$ \\
\hline South East & $\begin{array}{l}26 / 09 / 2016 \\
\text { o80o-130ohrs }\end{array}$ & Gaborone NDB Building Offices \\
\hline Kgatleng & $\begin{array}{l}\text { 03/10/2016 } \\
\text { 0900 - 120ohrs }\end{array}$ & $\begin{array}{l}\text { Mochudi Education \& Media } \\
\text { Centre }\end{array}$ \\
\hline Central & $\begin{array}{l}\text { 05/10/2016 } \\
\text { 0900-120ohrs }\end{array}$ & Serowe Regional Offices \\
\hline
\end{tabular}

Table A3

Field Visit Schedule for the 10 Regions of Cameroon

\begin{tabular}{|l|l|l|}
\hline Region & Date and time & Venue \\
\hline East & $\begin{array}{l}14 / 10 / 2016 \\
9 \mathrm{am}-11 \mathrm{am}\end{array}$ & $\begin{array}{l}\text { Conference Hall, Regional } \\
\text { Delegation MINESEC . }\end{array}$ \\
\hline South & $\begin{array}{l}17 / 10 / 2016 \\
10 \mathrm{am}-12 \mathrm{pm}\end{array}$ & $\begin{array}{l}\text { ENIEG Conference Hall } \\
\text { EBOLOWA. }\end{array}$ \\
\hline Centre & $\begin{array}{l}18 / 10 / 2016 \\
10 \mathrm{am}-12 \mathrm{pm}\end{array}$ & $\begin{array}{l}\text { Conference Hall, Regional } \\
\text { Delegation MINEDUB. }\end{array}$ \\
\hline West & $\begin{array}{l}20 / 10 / 2016 \\
11 \mathrm{am}-1 \mathrm{pm}\end{array}$ & $\begin{array}{l}\text { Conference Hall, Regional } \\
\text { Delegation of MINESEC. }\end{array}$ \\
\hline North West & $21 / 10 / 2016$ \\
$9 \mathrm{am}-11 \mathrm{pm}$ & $\begin{array}{l}\text { Conference Hall, Regional } \\
\text { Delegation of MINESEC. }\end{array}$ \\
\hline South West & $\begin{array}{l}24 / 10 / 2016 \\
9 \mathrm{am}-11 \mathrm{am}\end{array}$ & $\begin{array}{l}\text { Conference Hall, Regional } \\
\text { Delegation MINEDUB. }\end{array}$ \\
\hline Littoral & $25 / 10 / 2016$ & Conference Hall, Regional \\
\hline
\end{tabular}




\begin{tabular}{|l|l|l|}
\hline & 9 am $-11 \mathrm{am}$ & Delegation MINEDUB. \\
\hline Far North & $\begin{array}{l}31 / 10 / 2016 \\
9 \mathrm{am}-11 \mathrm{am}\end{array}$ & $\begin{array}{l}\text { Conference Hall, Regional } \\
\text { Delegation MINEDUB. }\end{array}$ \\
\hline North & $\begin{array}{l}01 / 11 / 2016 \\
9 \mathrm{am}-11 \mathrm{am}\end{array}$ & $\begin{array}{l}\text { Conference Hall, Regional } \\
\text { Delegation MINEDUB. }\end{array}$ \\
\hline Adamaoua & $03 / 11 / 2016$ & $\begin{array}{l}\text { Conference Hall, Regional } \\
\text { Delegation MINESEC. }\end{array}$ \\
& $9 \mathrm{am}-11 \mathrm{am}$ & \\
\hline
\end{tabular}

\section{Athabasca}

University

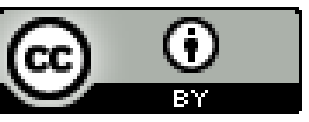

